\title{
A guide to laboratory diagnosis of Corona Virus Disease-19 for the gastroenterologists
}

\author{
Ujjala Ghoshal $^{1} \cdot$ Shruthi Vasanth ${ }^{1} \cdot$ Nidhi Tejan ${ }^{1}$ \\ Received: 21 June 2020 / Accepted: 21 July 2020 /Published online: 2 September 2020 \\ (C) Indian Society of Gastroenterology 2020
}

\begin{abstract}
The outbreak of Corona Virus Disease-19 (COVID-19), caused by Severe Acute Respiratory Syndrome Corona Virus - 2 (SARS-CoV-2), a global pandemic, is having a significant impact on healthcare, especially the clinical microbiology laboratories all around the world. There are many reports which suggest that the disease can present with gastrointestinal symptoms such as nausea, vomiting, diarrhea, and loss of appetite, which the gastroenterologists may have to deal with. Hence, knowledge about the diagnosis of COVID-19 is important to gastroenterologists as well. The current review therefore covers the challenges faced while choosing appropriate sample collection, transport, and tests for SARS-CoV-2 infection. The right sample at the right time from the right anatomical site with the proper precautions is crucial in prompt and accurate diagnosis of COVID-19. The tests can be divided into direct, indirect, and complementary tests. In the direct test, real-time polymerase chain reaction (RT-PCR) assays are the molecular tests of choice for the diagnosis of COVID-19. Other direct tests include GeneXpert and TrueNAT. In indirect testing, antigen-antibody-based techniques are recommended for surveillance for the disease, which may help to formulate the control measures. Finally, the additional tests help in assessing the disease severity and evaluating the prognosis. All the above tests are important not only for diagnosis but also for management strategy and prognosis.
\end{abstract}

Keywords Beta coronavirus · COVID-19 $\cdot$ Novel Corona virus $\cdot$ Pandemic $\cdot$ Real-time PCR $\cdot$ Severe acute respiratory syndrome $\cdot$ TrueNAT $\cdot$ Viral pneumonia

\section{Introduction}

Corona Viruses are positive-stranded ribonucleic acid (RNA) viruses, which belong to the Coronaviridae family. These viruses cause illness, which may range from asymptomatic infections or mild flu to severe disease like pneumonia [1-3]. The recently emerged strain, Severe Acute Respiratory Syndrome Corona Virus - 2 (SARS-CoV-2), also has a varied presentation.

In a recent systematic review, data from 29 studies including 6064 cases showed that the prevalence of gastrointestinal (GI) symptoms was 15\% among patients with Corona Virus Disease-19 (COVID-19) [4]. It was also observed that nearly $10 \%$ of patients had only GI symptoms. Feco-oral transmission can be one potential route for

Ujjala Ghoshal

ujjalaghoshal@yahoo.co.in

1 Department of Microbiology, Sanjay Gandhi Post Graduate Institute of Medical Science, Lucknow 226 014, India transmission of the disease apart from respiratory route [5]. A study testing different samples from patients with SARSCoV-2 infection observed that around 29\% fecal samples were positive for viral nucleic acid [6]. In another study by $\mathrm{Xu}$ et al., rectal swabs in 8 of 10 pediatric patients with COVID-19 were persistently positive even after nasopharyngeal samples became negative [7].

Arriving at an early diagnosis in such patients with no respiratory symptom is important to prevent delay in treatment and transmission of infection. The preferred testing method is the real-time reverse transcriptase-polymerase chain reaction (RT-PCR). Other tests, GeneXpert and TrueNAT, based on nucleic acid amplification are used in the resource-limited areas with less expertise [8-11] (https://www.who.int/ emergencies/diseases/novel-coronavirus-2019/technicalguidance/early-investigations). Viral culture is not recommended for routine diagnosis. It is of importance during environmental and the sewage surveillance and cannot be done in resource-limited setup [12]. This manuscript guides in the selection, performance, interpretation of test results, biosafety, and other current issues in the diagnosis 
as well as prognosis of COVID-19, catering to the needs of clinicians including gastroenterologists, clinical microbiologists, and public health specialists.

\section{Laboratory diagnosis}

Laboratory diagnosis plays a vital role in early identification, isolation, treatment, and prevention of morbidity and mortality and curtailing the transmission of SARS-CoV-2 infection. It involves direct, indirect, and complementary tests (Table 1). Direct tests are used for identifying the disease-causing agent from the patients. Indirect tests are used to identify the immune response of the host to the disease. Before selecting the type of test, pre-analytical procedures constitute a crucial part of the diagnosis of any infectious disease [12].

\section{Pre-analytical procedures}

Pre-analytical procedures include categorizing the patients based on the risk stratification, deciding the type of sample to be collected, collection methods, and sample transport.

Specimen collection and shipment Before collection, adequate training must be given to staff regarding the standard operational procedures for collection and transport of samples as well as the biosafety measures. The sensitivity for the detection of Corona Virus is high if samples from both the upper and lower respiratory tracts are collected. High viral loads were observed in the respiratory tract within 5-6 days of symptom onset [12]. The upper respiratory samples include nasopharyngeal (NP) and oropharyngeal (OP) specimens. In a study, the sensitivity of OP swabs for the detection of SARSCoV-2 RNA was $32 \%$ as compared with NP swabs of $63 \%$ [6, 10]. Lower respiratory tract samples may also be used. These include sputum, lung biopsy, bronchoalveolar lavage (BAL), and tracheal aspirate, which may be collected in intubated patients. The collection of lower respiratory tract samples is usually associated with the generation of aerosols, which poses a risk to the healthcare workers (HCWs). Bronchoscopy for collection of BAL is an invasive procedure and requires well-trained staff and may not be available in all settings.

Table 1 Various tests used for management of Corona Virus Disease-19
The Center for Disease Control and Prevention (CDC) recommends that if NP and OP swabs are being collected, these must be placed in the same collection tube containing the viral transport medium (VTM) (https://www.cdc.gov/coronavirus/ 2019-ncov/lab/guidelines-clinical-specimens.html). Swabs should be collected using synthetic fiber with plastic or wire shafts. For obtaining a NP sample, a swab is inserted through the nostril parallel to the palate until resistance is felt indicating encounter with the nasopharynx. The swab should cover a distance equal to that from nostrils to the outer opening of the ear. The swab is then gently rubbed and left in place for several seconds to absorb secretions, then removed slowly. The same swab can be used to collect a sample from both the sides. For the collection of OP sample, another swab is rubbed over both tonsillar pillars and posterior oropharynx. A properly inserted NP swab usually causes tear formation in patients, while a properly placed OP swab should elicit a gag reflex [12]. Calcium alginate swabs or swabs with wooden shafts should not be used as these may contain substances that inactivate some viruses and inhibit PCR testing. The collected samples should be placed immediately into a sterile transport tube containing $2-3 \mathrm{~mL}$ of VTM. Swabs and other specimens may be stored at $2-8{ }^{\circ} \mathrm{C}$ for up to $72 \mathrm{~h}$ after collection. If a delay in testing or shipping is expected, the specimens should be stored at $-70{ }^{\circ} \mathrm{C}$ or below. Samples must be packaged, shipped, and transported according to the International Air Transport Association (IATA) guidelines in a triple-layered fashion. It has to be duly labeled with the biohazard symbol and the patient details (https://www.cdc.gov/coronavirus/2019-ncov/lab/ guidelines-clinical-specimens.html).

For sputum collection, its induction is not recommended. Samples should be collected wearing complete personal protective equipment (PPE) due to the risk of generation of aerosols [12]. Proper and appropriate collection of specimens is the most crucial step in the laboratory diagnosis of any respiratory infection. If not collected properly, it may lead to falsenegative test results [13]. Other samples like blood, serum, stool, urine, and the other body fluids and sewage specimens have also shown to give effective results in the diagnosis and surveillance of the SARS-CoV-2 infection [14].

Fecal samples Approximately $10 \mathrm{~g}$ of feces may be collected in a wide-mouthed clean container. A stool suspension is made in isotonic saline solution or phosphate-buffered saline,

\begin{tabular}{ll}
\hline Direct tests & Indirect test \\
\hline $\begin{array}{l}\text { Real-time reverse transcriptase-polymerase chain reaction } \\
\text { (preferred) }\end{array}$ & $\begin{array}{c}\text { Antigen and antibody detection by serological } \\
\text { assays }\end{array}$ \\
Xpert® Xpress SARS-CoV-2 & \\
TrueNAT & \\
\hline
\end{tabular}

SARS-CoV-2 Severe Respiratory Distress Syndrome Corona Virus-2 
Table 2 Sensitivity of different clinical samples by real-time polymerase chain reaction (RT-PCR)

\begin{tabular}{lc}
\hline Sample type & Sensitivity \\
\hline Nasal swab [5] & $63 \%$ \\
Pharyngeal swab [5] & $32 \%$ \\
Feces [5, 18] & $48.1 \%$ \\
Blood [5, 18] & $1-3 \%$ \\
Sputum [5, 18] & $72-75 \%$ \\
Bronchoalveolar lavage [5, 18] & $93-95 \%$ \\
\hline
\end{tabular}

which is centrifuged at 8000 revolution per minute (RPM) for $5 \mathrm{~min}$. Supernatant is then collected for the detection of virus. Samples should be tested as soon as possible and stored at $4{ }^{\circ} \mathrm{C}$; if delay of $>24 \mathrm{~h}$ is expected, these can be stored at $70{ }^{\circ} \mathrm{C}$ (http://www.chinacdc.cn/en/COVID19/202003/ P020200308322036088669.pdf). Anal swabs can also be collected by inserting a swab up to a depth of $3-5 \mathrm{~cm}$, rotating it and pulling it out. The sample is transferred into a collection tube with viral preserving solution (http://www.chinacdc.cn/ en/COVID19/202003/P020200308322036088669.pdf). Many studies have shown the varying excretion of virus in the stool, but not all the studies provided evidence to evaluate relationship between viral excretion in the stool and the presence of GI symptoms. Due to the inadequate data to prove its relevance, it is still advised to test both the OP and NP samples $[15,16]$. To summarize, the sensitivity data for the detection of SARS-CoV-2 RNA in various samples by RT-PCR have been listed in Table 2.

\section{Safety measures for specimen processing for PCR and other tests}

All specimens collected for laboratory investigations should be regarded as potentially infectious. One must ensure that HCWs collecting samples adhere rigorously to infection prevention and control guidelines according to the World Health
Organization (WHO), which has been published for laboratory biosafety [21]. The respiratory specimens should be processed in class II biological safety cabinet (https:/www.who. int/emergencies/diseases/novel-coronavirus-2019/technicalguidance/early-investigations) [12, 17]. Samples should be transferred and stored properly as heating might degrade the RNA $[18,19]$. In self-enclosed integrated nucleic acid extraction, amplification, and detection systems such as Cobas (Roche Molecular Systems, Pleasanton, CA, US), GeneXpert (Cepheid, Sunnyvale, CA, US), and TrueNAT (Molbio Diagnostics Pvt. Ltd., Tirupati, India), the samples from media are transferred into a cartridge in a class II biosafety cabinet, after which the cartridge is sealed [20].

The samples will be processed inside the biosafety level 2 (BSL-2) laboratory with all the standard contact precautions. Any breach in the good laboratory practices and safety techniques of BSL-2 might expose the technician for the unprecedented event. To date, there is lack of data on laboratory outbreak of SARS-CoV-2 infection [21]. BSL-2 should be used when nucleic acid handling and storage of SARS-CoV2 is done to avoid any exposure to the technician. In India, according to Indian Council of Medical Research (ICMR) guidelines, we discard the samples in a biohazard bag containing $2 \%$ lyzol or $5 \%$ freshly prepared sodium hypochlorite solution after sealing the bag. According to the national guidelines, these discarded samples will be treated as infectious waste and sent for further processing [22].

\section{Assay selection}

The molecular diagnostic tests are being the preferred method for the diagnosis of SARS-CoV-2 infection. The RT-PCR assay is considered as the current gold standard assay for confirmatory diagnosis of COVID-19 [8, 10, 18, 23].

\section{Target selection for RT-PCR assays}

The various organizations, like CDC (USA), have approved various kits [24]. Different manufacturers have used different

Table 3 Limit of detection of different nucleic acid-based tests

\begin{tabular}{|c|c|c|c|c|}
\hline Types of tests & Targets & Limit of detection (LOD) & $\begin{array}{l}\text { Positive percent } \\
\text { agreement }(95 \% \mathrm{CI})\end{array}$ & $\begin{array}{l}\text { Negative percent } \\
\text { agreement }(95 \% \mathrm{CI})\end{array}$ \\
\hline Real-time RT-PCR & $\begin{array}{l}\text { E gene } \\
\text { RdRp } \\
\text { N2 gene } \\
\text { Orflb } \\
\text { S gene }\end{array}$ & $\begin{array}{l}<10 \text { copies } / \mathrm{mL} \\
\quad(\text { varies from kit to kit) }\end{array}$ & $100 \%$ & $100 \%$ \\
\hline Xpert@ Xpress SARS-CoV-2 & $\begin{array}{l}\text { E gene } \\
\text { N2 gene }\end{array}$ & 250 copies $/ \mathrm{mL}$ & $100 \%$ & $100 \%$ \\
\hline TrueNAT & $\begin{array}{l}\text { RdRp } \\
\text { E gene }\end{array}$ & 486 copies $/ \mathrm{mL}$ & $100 \%$ & $100 \%$ \\
\hline
\end{tabular}

$R T-P C R$ reverse transcriptase-polymerase chain reaction, $C I$ confidence interval 


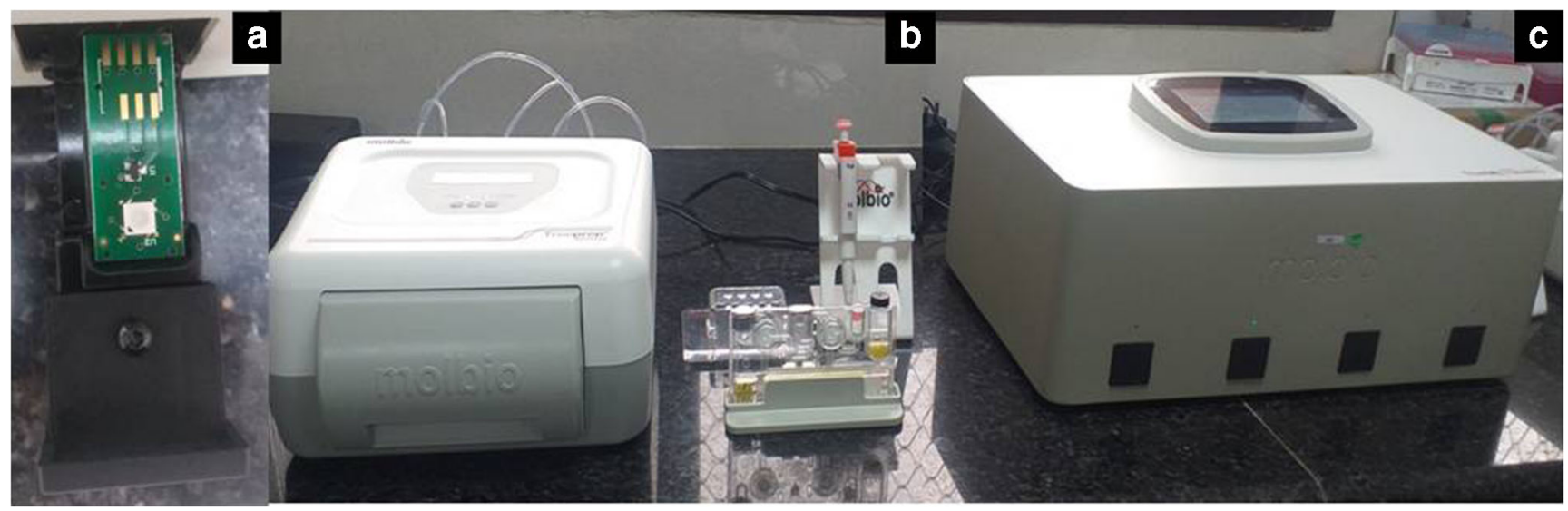
India). a The PCR microchip used for amplification of the nucleic acid. b The nucleic acid extractor towards the left side, amplifier towards the
Fig. 1 Diagram of TrueNAT (Molbio Diagnostics Pvt. Ltd., Tirupati,

right side with a calibrated pipette, and the AUTO Universal CartridgeBased Sample Prep® Trueprep kit

\section{Interpretation of molecular test results}

genes like an envelope $(\mathrm{E})$, spike $(\mathrm{S})$, nucleocapsid $(\mathrm{N})$, membrane (M), and helicase (Hel) genes [26-28]. In addition to the above genes, there are some species-specific accessory genes, which help in viral replication, like RNA-dependent RNA polymerase (RdRp) gene, hemagglutinin-esterase (HE) gene, and open reading frame 1a (ORF1a) gene, and ORF1b gene [9, 24-27]. The WHO recommends screening with an E gene followed by a confirmatory test using the RdRp gene to avoid cross-reaction with other endemic coronaviruses due to the genetic drift of SARS-CoV-2 [9]. Assay performance is usually dictated by the reagent design, not the target itself, since the viral genes are present in equal copy numbers.

Post-analytical issues This involves the interpretation of molecular results and reporting.

In most of the symptomatic patients, viral RNA is measured by cycle threshold $(\mathrm{Ct}$ ), which can be detected as early as day 1 and peaks in the first week after onset of symptoms [29]. The Ct value is the number of cycles of amplification required to generate a fluorescent signal. Thus, lower values of $\mathrm{Ct}$ will mean high viral RNA load [28]. These Ct values have no direct or indirect correlation with the severity of the disease, whereas the $\mathrm{Ct}$ values can be inversely proportional to the viral load present in the sample and thus the transmissibility $[14,28,30]$.

The interpretation of the result is specific to the kit; i.e. in the CDC-recommended kit, if both the genes test positive, then the test will be considered positive (genes N1, N2); if the $\mathrm{Ct}$ value is less than 40 and if only one gene tests positive, it will be reported as indeterminate and repeat testing has to be done for confirmation [24]. By the 3rd week, positivity declines and,
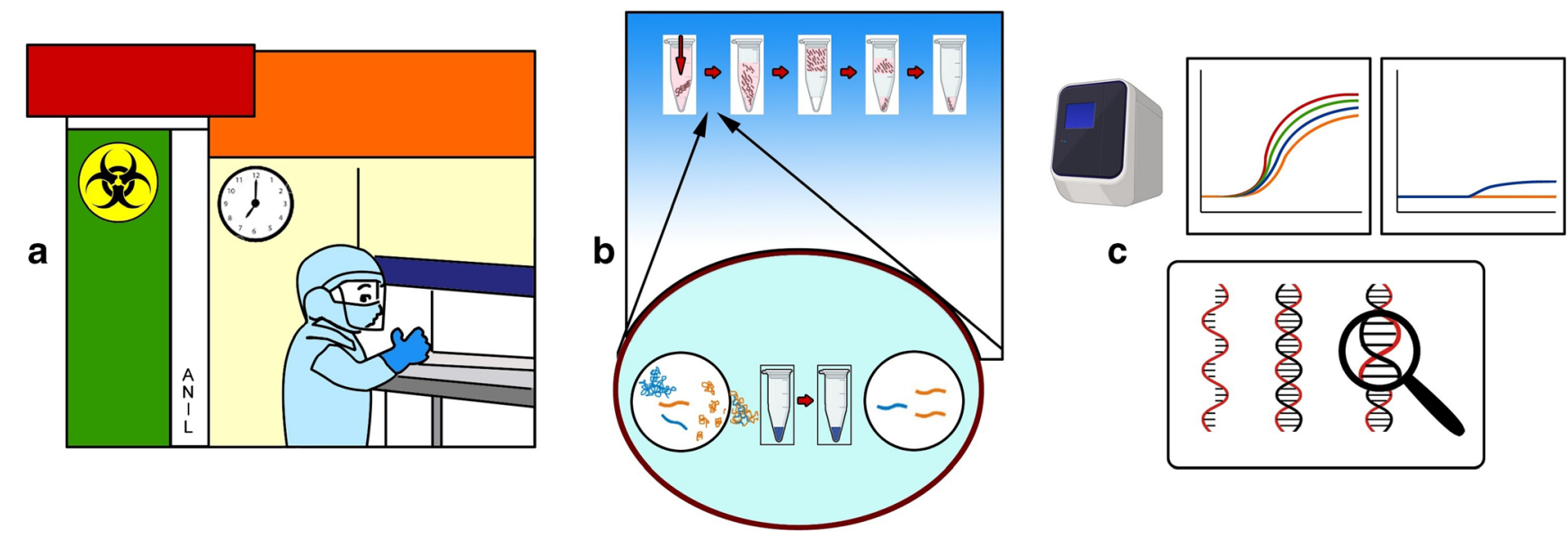

C

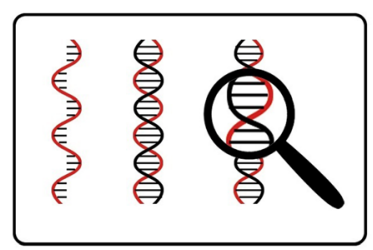

Fig. 2 a The laboratory worker in full personal protective equipment (PPE) processing the samples from patients with Corona Virus Disease (COVID19 ) in the biosafety cabinet. b The nucleic acid extraction from the virus. $\mathbf{c}$ Polymerase chain reaction (PCR) machine amplifying the desired target 
Table 4 Limitation and advantage of TrueNAT over Xpert® Xpress SARS-CoV-2

\begin{tabular}{|c|c|c|}
\hline $\begin{array}{l}\text { SL } \\
\text { No. }\end{array}$ & TrueNAT & Xpert ${ }^{\circledR}$ Xpress SARS-CoV-2 \\
\hline 1 & Chip-based assay & Cartridge-based assay \\
\hline 2 & Target: RNAase P, RdRp gene & E gene, $\mathrm{N} 2$ gene \\
\hline 3 & $\begin{array}{l}\text { Advantages } \\
\text { a. Battery operable } \\
\text { b. No need of air-conditioned rooms } \\
\text { c. Cost-effective } \\
\text { d. Indigenous company, thus good availability } \\
\text { e. Less risk of aerosol generation, as viral lysis media lyses most of the infectious } \\
\text { material }\end{array}$ & $\begin{array}{l}\text { Limitations } \\
\text { a. Power operable } \\
\text { b. Needs air-conditioned room } \\
\text { c. More risk of aerosol generation }\end{array}$ \\
\hline 4 & $\begin{array}{l}\text { Limitations } \\
\text { a. It is a } 2 \text {-step process, since it works on } 2 \text { genes } \\
\text { b. Limit of detection is more, i.e. } 486 \text { copies } / \mathrm{mL}\end{array}$ & $\begin{array}{l}\text { Advantages } \\
\text { a. Single-step process } \\
\text { b. Limit of detection is less than TrueNAT, i.e. } 250 \\
\text { copies } / \mathrm{mL}\end{array}$ \\
\hline
\end{tabular}

SARS-CoV-2 Severe Respiratory Distress Syndrome Corona Virus-2

after that, becomes undetectable [29]. Sometimes, the positivity may persist even beyond 6 weeks after the first test [29].

\section{Other nucleic acid-based tests}

TrueNAT and Xpert ${ }^{\circledR}$ Xpress SARS-CoV-2 tests are based on nucleic acid amplification (NAAT), which was earlier used for tuberculosis detection [11]. The targets are E gene and N2 gene in Xpert and RdRp gene in TrueNAT with a limit of detection of 250 copies $/ \mathrm{mL}$ and 486 copies $/ \mathrm{mL}$, respectively (Table 3) [11] (http://www.molbiodiagnostics.com/uploads/product download/ 20200526.133547 Final-Truenat-SARS-CoV-2-packinsertVER-02.pdf). Laboratories that have installed TrueNAT and GeneXpert under Revised National Tuberculosis Control Program (RNTCP) of the Ministry of Health and Family Welfare, Government of India, but do not have expertise, human resources, and infrastructure to perform RT-PCR are provided with these test kits by ICMR. Currently, these kits are not available commercially and are procured and supplied by ICMR. TrueNAT has an edge compared with GeneXpert ${ }^{\circ}$ since it works on a battery and also without the need for an air conditioner as needed for other nucleic acid amplification tests (Fig. 1) [31]. For TrueNAT samples have to be sent in viral lysis media (VLM) and not in VTM. Limitations of TrueNAT and Xpert® Xpress SARS-CoV-2 are summarized in Table 4. Figure 2 shows the schematic diagram of sample preparation within the biosafety cabinet, nucleic acid extraction, and RT-PCR.

\section{Indirect test}

\section{Serology of COVID-19}

Serological assays based on the detection of antibodies help in outbreak investigation and seroprevalence studies. Seroprevalence studies help as an indirect indicator to see the percentage of the population who can get infected due to the virus, which helps for the preparation of subsequent waves of infection.

These assays are available on various platforms like enzyme-linked immunosorbent assay (ELISA), rapid diagnostic tests in the form of lateral flow assay, and enzyme-linked fluorescent assay (ELFA) (VIDAS®, SARS-CoV-2 serology, Biomerieux, France). However, these tests are not recommended for diagnostic purposes due to the cross-reactivity with other endemic coronaviruses, which usually cause usual type of flu in the community $[31,32]$. One study showed that only $<40 \%$ of patients had detectable antibodies during the first 6-7 days of COVID-19 [33]. A positive test may indicate past infection with the virus. Various test kits have been made available in the market for detecting the antigen in the serum of the patients. However, the duration and dynamics of the secretion of the protein antigens have not been established. Therefore, the negative result cannot be used as a criterion to rule out the infection with SARS-CoV-2 (https://www.paho. org/en/documents/laboratory-guidelines-detection-anddiagnosis-covid-19-virus-infection).

\section{Supplementary tests}

These help in assessing the disease severity and prognosis. The tests like complete hemogram, liver function test, renal function test, coagulation profile, chest X-ray, and highresolution computerized tomography (HRCT) scan of lungs help detecting degree of involvement of different organs and systems in patients with COVID-19.

\section{Vulnerabilities in the diagnostic procedures}

The potential vulnerabilities include pre-analytical issues such as problems in identification, inappropriate or inadequate 
collection, handling, maintenance of the cold chain during transport, fluctuation in storage temperature, presence of interfering substances, manual errors, and sample contamination. There are various analytical issues like testing outside the diagnostic window, active viral recombination, inadequately validated assays, and instrument malfunctioning. Post-analytical vulnerabilities like errors and delay in reporting should be noted. These can be identified and minimized by dissemination of clear instructions for specimen collection, management, and storage, along with the refinement of molecular targets and thorough compliance with analytical procedures, with quality assurance [34].

\section{Cost-effective approach for testing}

Low- and middle-income countries (LMIC) are facing the brunt of the disease with limited access to the expertise, materials, and infrastructure. As proposed by the ICMR, five samples of the different patients can be pooled together and can be tested (pool testing) [35]. The approach of collecting the samples of 5 members of the same family with mild or no symptom in a single VTM can be tried. Extended use of PPE may be considered according to the CDC strategy to reduce the economic burden and to minimize the human resources required [36]. As the lockdown has already hit these LMIC countries economically, further brunt can be decreased by rationalizing the test and the approach.

India's strategic testing approach has been complemented by the prolonged national lockdown while ICMR is trying to ramp-up its testing capabilities by providing kits to various laboratories as well as by using different innovative methods for the peripheral laboratories, which lack the infrastructure to perform RT-PCR. The accurate laboratory diagnosis of COVID-19 will help in preventing its spread. India is all set to cater to the increasing needs of testing by a multimodal approach [31].

\section{Compliance with ethical standards}

Conflict of interest UG, SV, and NT declare that they have no conflict of interest.

Disclaimer The authors are solely responsible for the data and the contents of the paper. In no way, the Honorary Editor-in-Chief, Editorial Board Members, or the printer/publishers are responsible for the results/ findings and content of this article.

\section{References}

1. Azhar EI, Hui DSC, Memish ZA, Drosten C, Zumla A. The Middle East Respiratory Syndrome (MERS). Infect Dis Clin N Am. 2019;33:891-905.
2. Drosten C, Preiser W, Günther S, Schmitz H, Doerr HW. Severe acute respiratory syndrome: identification of the etiological agent. Trends Mol Med. 2003;9:325-7.

3. Hui DSC, Zumla A. Severe acute respiratory syndrome: historical, epidemiologic, and clinical features. Infect Dis Clin N Am. 2019;33:869-89.

4. Mao R, Qiu Y, He J-S, et al. Manifestations and prognosis of gastrointestinal and liver involvement in patients with COVID-19: a systematic review and meta-analysis. Lancet Gastroenterol Hepatol. 2020;5:667-78.

5. Yang L, Tu L. Implications of gastrointestinal manifestations of COVID-19. Lancet Gastroenterol Hepatol. 2020;5:629-30.

6. Wang W, Xu Y, Gao R, et al. Detection of SARS-CoV-2 in different types of clinical specimens. JAMA. 2020;323:1843-4.

7. $\mathrm{Xu} \mathrm{Y,} \mathrm{Li} \mathrm{X,} \mathrm{Zhu} \mathrm{B,} \mathrm{et} \mathrm{al.} \mathrm{Characteristics} \mathrm{of} \mathrm{pediatric} \mathrm{SARS-CoV-2}$ infection and potential evidence for persistent fecal viral shedding. Nat Med. 2020;26:502-5.

8. Chu DK, Pan Y, Cheng SM, et al. Molecular diagnosis of a novel coronavirus (2019-nCoV) causing an outbreak of pneumonia. Clin Chem. 2020;66:549-55.

9. Corman VM, Landt O, Kaiser M, et al. Detection of 2019 novel coronavirus (2019-nCoV) by real-time RT-PCR. Euro Surveill. 2020;25:2000045.

10. Loeffelholz MJ, Tang YW. Laboratory diagnosis of emerging human coronavirus infections-the state of the art. Emerg Microbes Infect. 2020;9:747-56.

11. Ravichandran K, Anbazhagan S, Agri H, et al. Global status of COVID-19 diagnosis: an overview. J Pure Appl Microbiol. 2020;14:879-92.

12. Tang YW, Schmitz JE, Persing DH, Stratton CW. Laboratory diagnosis of COVID-19: current issues and challenges. J Clin Microbiol. 2020;58:e0512-20.

13. Pan Y, Zhang D, Yang P, Poon LLM, Wang Q. Viral load of SARS-CoV-2 in clinical samples. Lancet Infect Dis. 2020;20: 411-2.

14. Ahmed W, Angel N, Edson J, et al. First confirmed detection of SARS-CoV-2 in untreated wastewater in Australia: a proof of concept for the wastewater surveillance of COVID-19 in the community. Sci Total Environ. 2020;728:138764.

15. Amirian ES. Potential fecal transmission of SARS-CoV-2: current evidence and implications for public health. Int J Infect Dis. 2020;95:363-70.

16. Ghoshal UC, Ghoshal U, Dhiman RK. Gastrointestinal and hepatic involvement in severe acute respiratory syndrome coronavirus 2 infection: a review. J Clin Exp Hepatol.

17. Emery SL, Erdman DD, Bowen MD, et al. Real-time reverse transcription-polymerase chain reaction assay for SARSassociated coronavirus. Emerg Infect Dis. 2004;10:311-6.

18. Chan PK, To WK, Ng KC, et al. Laboratory diagnosis of SARS. Emerg Infect Dis. 2004;10:825-31.

19. Arnold PR, Lord NP, Smith AN, Bybee SM. The effects of nonideal temperature regimes on RNA quality from samples stored in RNAlater like buffer: An attempt to replicate fiels conditions. J Analyt Molecul Tech. 2016;2:8.

20. Ling L, Kaplan SE, Lopez JC, Stiles J, Lu X, Tang YW. Parallel validation of three molecular devices for simultaneous detection and identification of influenza A and B and respiratory syncytial viruses. J Clin Microbiol. 2018;56:e1691-17.

21. World Health Organization. Laboratory biosafety guidance related to the novel coronavirus (2019-nCoV). Interim guidance Available from URL: https://www.who.int/docs/defaultsource/coronaviruse/ laboratory-biosafety-novel-coronavirus-version-1-1.pdf.2020.

22. Notification of ICM testing in private COVID labs in India by MOHFW. https://www.mohfw.gov.in/pdf/ NotificationofICMguidelinesforCOVID19testingin privatelaboratoriesiIndia 
23. Blow JA, Dohm DJ, Negley DL, Mores CN. Virus inactivation by nucleic acid extraction reagents. J Virol Methods. 2004;119:195-8.

24. Holshue ML, DeBolt C, Lindquist S, et al. First case of 2019 novel coronavirus in the United States. N Engl J Med. 2020;382:929-36.

25. Cui J, Li F, Shi ZL. Origin and evolution of pathogenic coronaviruses. Nat Rev Microbiol. 2019;17:181-92.

26. Lu R, Zhao X, Li J, et al. Genomic characterisation and epidemiology of 2019 novel coronavirus: implications for virus origins and receptor binding. Lancet. 2020;395:565-74.

27. Chan JF, Yip CC, To KK, et al. Improved molecular diagnosis of COVID-19 by the novel, highly sensitive and specific COVID-19$\mathrm{RdRp} / \mathrm{Hel}$ real-time reverse transcription-PCR assay validated in vitro and with clinical specimens. J Clin Microbiol. 2020;58: e00310-20.

28. Li Q, Guan X, Wu P, et al. Early transmission dynamics in Wuhan, China, of novel coronavirus-infected pneumonia. N Engl J Med. 2020;382:1199-207.

29. Report of the WHO-China Joint Mission on Coronavirus Disease 2019 (COVID-19) World Health Organization (WHO).

30. Cheng VC, Wong SC, Chen JH, et al. Escalating infection control response to the rapidly evolving epidemiology of the coronavirus disease 2019 (COVID-19) due to SARS-CoV-2 in Hong Kong. Infect Control Hosp Epidemiol. 2020;41:493-8.

31. Chan CM, Tse H, Wong SS, et al. Examination of seroprevalence of coronavirus HKU1 infection with $\mathrm{S}$ protein-based ELISA and neutralization assay against viral spike pseudotyped virus. J Clin Virol. 2009;45:54-60.

32. Meyer B, Drosten C, Muller MA. Serological assays for emerging coronaviruses: challenges and pitfalls. Virus Res. 2014;194:17583.

33. Zhao J, Yuan Q, Wang H, et al. Antibody responses to SARS-CoV2 in patients of novel coronavirus disease 2019. Clin Infect Dis. 2020; ciaa344.

34. Lippi G, Simundic AM, Plebani M. Potential preanalytical and analytical vulnerabilities in the laboratory diagnosis of coronavirus disease 2019 (COVID-19). Clin Chem Lab Med. 2020;58:1070-6.

35. Advisory on feasibility of using pooled samples for molecular testing of COvID-19 https://www.mohfw.gov.in/pdf/ letterregguidanceonpoolingsamplesfortesting001.pdf

36. Operational Considerations for Personal Protective Equipment in the Context of Global Supply Shortages for Coronavirus Disease 2019 (COVID-19) Pandemic: non-US Healthcare Settings https:// www.cdc.gov/coronavirus/2019-ncov/hcp/non-us-settings/ emergency-considerations-ppe.html

Publisher's note Springer Nature remains neutral with regard to jurisdictional claims in published maps and institutional affiliations. 